\title{
Capacity Assessments for Improving Corporate Efficiency - Case of Limassol Turkish Cooperative Bank in Northern Cyprus
}

\author{
Mustafa Ertanın and Okan Veli Şafaklı \\ European University of Lefke, Faculty of Business and \\ Economics Department of Business Administration, Lefke \\ North Cyprus
}

\section{Introduction}

Ever increasing challenges in real and financial sectors, the more so often global and territorial crises, the concentration and adjustments in banking regulations, the increased competition level in banking (due to deregulations and cross-border banking competitions) and the social factors such as banking ethics, customers' maturing perception of bank services, consumer satisfaction add pressure to any bank's Board of Directors (BOD) for paving new paths in overall management directions. Sustainability concerns and social responsibilities create a new and more complicated mix in which the bank employees at all levels continue to be a major factor reasoning the success and profitability levels of the organization.

Periodical staff and management performance evaluations are now more than a trendy tradition in corporations. Outcomes of performance evaluation affect the staff structure in both management and operations. Performance evaluations use criteria to evaluate the overall ability of staff in fulfilling the duties and tasks assigned to them. The results also indicate the employees' corporate values and social responsibility values. Employees subject to any performance evaluation are expected to be staff with appropriate education, training, experience, and ability to manage the tasks and duties that, their job requires.

This study evaluates the necessity of Capacity Assessment to employees prior to exercising performance evaluation to them. By implying Capacity Assessment, staff is initially evaluated if they are equipped with knowledge enough to handle the tasks. Capacity Assessment will also scale the corporate attitude of the employee. Team-workers, leaders, innovators, communicators, and silent abilities are filtered, whereas each one's strengths and underdeveloped skills are projected in the outcome.

Methodology of the study and the challenges to ensure participation of the Board (Saskatoon, 2004) are as follows:

- Briefing and motivating the employees for professional participation

- Criteria selection with the participation of management and staff 
- $\quad$ Drawing the Capacity Assessment Questionnaire ${ }^{1}$

- Completing the Questionnaire as Balanced Scorecard with section for Top and Middle management (Kaplan and Norton ,1992)

- Employing the Personnel Department ${ }^{2}$ to schedule the interview process.

Capacity Assessments as in the case studied below will necessitate additional individual and corporate trainings, relocation of personnel, restructuring the departments and even reviewing the company major policies as the case may be.

Limasol Türk Kooperatif Bankası (LTK Bank) is a cooperative firm ${ }^{3}$ subject to the local company law and is operating as a commercial bank under supervision of local central bank and finance ministry. LTK Bank had a Central Branch and 11 branches and employed 170 including 15 top-level managers when the Capacity Assessment program was initiated in April 2010.

The program was implemented by experienced and qualified Corporate Educators, Mustafa Ertanin, ${ }^{4}$ and Huda Hudaverdi ${ }^{5}$. The Capacity Assessment interviews for the employees were also done by $\mathrm{M}$. Ertanin and $\mathrm{H}$. Hudaverdi.

BOD of LTK Bank and General Manager (GM) participated in some decision-making procedures.

The main structure of this study unique to LTK Bank consists of the Concept of Capacity Assessment and Capacity Development, corporate assessment process and conclusion respectively. This chapter is organized as follows: The first introductory part presents aim, scope, and methodology of the study. The second part explains the Concept of Capacity Assessment and Capacity Development. Third part is devoted to corporate assessment process. Corporate assessment process contents Drafting the project with BOD of LTK Bank; Ensuring the participation of BOD and GM; Briefing the staff and motivating them for professional participation and contribution; Drawing the questioner with key participants and forming the Balanced Scorecard; Interviews for Individual Capacity Assessments; Physical and Management Assessment of Branches and Departments; Evaluating the Data and Reporting to BOD; Capacity Assessment and suggestions to LTK Bank's BOD; and Summary of trainings as an outcome of the capacity assessment program correspondingly. The final part gives conclusive remarks about the study and informs the readers about the limitations of the study and the need of future research.

\section{The concept of capacity assessment and capacity development}

Capacity is defined as the ability of individuals and organisations or organizational units to perform functions effectively, efficiently and sustainably. Alternatively, capacity can be defined as "The ability of individuals, institutions and societies to perform functions, solve problems and set and achieve objectives in a sustainable manner (UNDP, 2007)", "the ability

\footnotetext{
${ }^{1}$ Key Performance Indicators as developed by Advanced Performance Institude and others

2 No HR dept was yet established.

${ }^{3}$ Popular public company type with large number of members owning shares

${ }^{4}$ Co-author of this chapter,Dr, Economics, Lecturer in European University of Lefke and with 30 years of experience in Corporate and Education Issues.

${ }^{5}$ Dr., Senior Lecturer in Girne American University, ex member of various Bank BODs
} 
of people, organizations and society as a whole to manage their affairs successfully (OECDDAC Network on Governance, 2006), and "ability of an organization to function as a resilient, strategic and autonomous entity (Kaplan, 2007)". These definitions imply that capacity is not a passive state but part of a continuing process and that human resources are central to capacity development. The overall context within which organisations undertake their functions are also key considerations in capacity development. Therefore, capacity is the power of something (a system, an organisation, a person) to perform or to produce (UNDP, 1998; UNDP, 2006).

The following five central characteristics or aspects of capacity can begin to give the theory and practice some substantive and operational shape (Morgan, 2006).

- Capacity is about empowerment and identity, properties that allow an organization or system to survive, to grow, diversify, and become more complex. To evolve in such a way, systems need power, control, and space. Capacity has to do with people acting together to take control over their own lives in some fashion.

- Capacity has to do with collective ability, i.e. that combination of attributes that enables a system to perform, deliver value, establish relationships and to renew itself. Or put another way, the abilities that allow systems - individuals, groups, organizations, groups of organizations - to be able to do something with some sort of intention and with some sort of effectiveness and at some sort of scale over time.

- Capacity as a state or condition is inherently a systems phenomenon. Capacity is an emergent property or an interaction effect. It comes out of the dynamics involving a complex combination of attitudes, resources, strategies, and skills, both tangible and intangible. It emerges from the positioning of a system within a particular context. In addition, it usually deals with complex human activities, which cannot be addressed from an exclusively technical perspective.

- Capacity is a potential state. It is elusive and transient. It is about latent as opposed to kinetic energy. Performance, in contrast, is about execution and implementation or the result of the application/use of capacity. Given this latent quality, capacity is dependent to a large degree on intangibles. It is thus hard to induce, manage, and measure. As a state or condition, it can disappear quickly particularly in smaller, more vulnerable structures. This potential state may require the use of different approaches to its development, management, assessment and monitoring.

- Capacity is about the creation of public value. All countries, regardless of their level of development, have many examples of effective capacity that subverts the public interest. The most obvious would be organized corruption, the behaviour of gangs and organized conspiracies, and the capture of public institutions. In most countries, different kinds of capacities compete for power, control, and resources.

Capacity Development ${ }^{6}$ is a concept that is broader than organizational development since it includes an emphasis on the overall system, environment, or context within which

\footnotetext{
${ }^{6}$ This is not much different than the OECD Development Assistance Committee (DAC) definition of Capacity Development, adapted by various donors, as "... the process by which individuals, groups, organizations, institutions and societies increase their abilities to: (1) perform core functions, solve problems, define and achieve objectives; and (2) understand and deal with their development needs in a broad context and in a sustainable manner." This definition goes on to define core capacities of an organization, or community,
} 
individuals, organisations, and societies operate and interact (and not simply a single organisation). In the case of development programmes, it includes a consideration of all factors, which affect upon its ability to be developed, implemented and the results to be sustained. Of special concern to development planners and to situations where there are limited resources is the need to build on what exists - to utilize and strengthen existing capacities, rather than to start from scratch . A Capacity Assessment is an analysis of desired capacities against existing capacities; this generates an understanding of capacity assets and needs, which informs the formulation of a capacity development response (UNDP, 2008). According to OECD, Capacity Assessment is structured and analytical process whereby the various dimensions of capacity are assessed within a broader context of systems, as well as evaluated for specific entities and individuals within these systems (OECD, 2006).

In addition to above, the more commonly used definitions of capacity development can be outlined as follows (Lusthaus et al., 1999):

- Capacity Development is a concept which is broader the organizational development since it includes an emphasis on the overall system, environment or context within which individuals, organizations and societies operate and interact (and not simply a single organization) (UNDP, 1998).

- Capacity Development is "... any system, effort or process... which includes among its major objectives strengthening the capability of elected chief executive officers, chief administrative officers, department and agency heads and program managers in general purpose government to plan, implement, manage or evaluate policies, strategies or programs designed to impact on social conditions in the community." (Cohen, 1993)

- Capacity Development: "The process by which individuals groups, organizations, institutions and societies increase their abilities: to perform functions solve problems and achieve objectives; to understand and deal with their development need in a broader context and in a sustainable manner" (UNDP, 1997)

- Capacity strengthening is an ongoing process by which people and systems, operating within dynamic contexts, enhance their abilities to develop and implement strategies in pursuit of their objectives for increased performance in a sustainable way" (Lusthaus et al. for IDRC, 1999).

\section{The capacity assessment process}

Addressing the questions 'capacity for whom?' and 'capacity for what?' helps determine the design of a capacity assessment. Key steps in this process are: Defining the scale and scope of the capacity assessment by selecting point of entry, core issue(s) and capacity(is); Defining desired capacity; Determining the data collection and analysis approach; and Reviewing existing data sources and knowledge (UNDP, 2008). As a result, of the UNDP's experience with capacity assessments to date. It is organized along the different steps of the capacity assessment process: 1) mobilize and design; 2) conduct the capacity assessment;

or sector, (or system) as consisting o f : defining, analyzing the environment or overall system, identifying needs and/or key issues, formulating strategies to respond to or meet needs, devising or implementing actions; assembling and using resources effectively and sustainably, monitoring performance, ensuring feedback, and adjusting courses of action to meet objectives, and acquiring new knowledge and skills to meet evolving challenges 
and 3) summarize and interpret results. During the second step of the capacity assessment process, the plan designed during the first step is carried out.

The capacity assessment team determines the level of desired capacities and assesses the level of existing capacities. This can be done through, for example, focus group discussions, self-assessment questionnaires, or one-on-one interviews (UNDP, 2009).

The Capacity Assessment program specially tailored for LTK Bank will follow the sequence of Drafting the project with BOD of LTK Bank; Ensuring the participation of BOD and GM; Briefing the staff and motivating them for professional participation and contribution; Drawing the questioner with key participants and forming the Balanced Scorecard; Interviews for Individual Capacity Assessments; Physical and Management Assessment of Branches and Departments; Evaluating the Data and Reporting to BOD; and Capacity Assessment and suggestions to LTK Bank's BOD.

Board of Directors, reporting to the Annual General Assembly composed of shareholder cooperative members initially was searching ways to improve the competitiveness of the Bank by either improving the individual performance of each employee or by replacing them with more equipped staff. The ruling vision was to motivate the employees to upgrade their knowledge in customer relations, more specifically in sales.

Time management was also an issue that BOD believed that needs attention. The management of the Bank faced dilemma; the traditional in house trained and experienced versus University educated bankers when selecting staff to be promoted and or assigned to new departments and divisions.

\subsection{Drafting the project with BOD of LTK Bank}

The journey of the bank to Capacity Assessment started with the search for external trainers to provide above up skilling to the staff and to evaluate the performance of the employees. This would justify the BOD's decisions in all staff matters like employment, wages, promotions etc. BOD thus intended to keep up with the increasing competition in the sector by both new local banks and foreign bank branches.

The Capacity Assessment program was suggested by the external evaluators as a method to analyse in more detail the staff and their knowledge and skills in relation with the duties they are assigned. BOD was briefed that they first need to know what the organisation is made of.

\subsection{Ensuring the participation of BOD and GM}

Data collected and processed during Capacity Assessment will clearly help to restructure the organisation to a better efficiency by upgrading the knowledge in needed areas and by reshuffling the employees to better matching positions. During the meetings with BOD, also a silent or indirect Capacity Assessment was implemented to the members by bringing to their attention how and what tools capacity assessors use in general. Spiedergram ${ }^{7}$ helped to

\footnotetext{
7 a drawing that shows a summary of facts or ideas, with the main subject in a central circle and the most important facts on lines drawn out from it, used invarious spheres of assessment, evaluation and planning
} 
clear the confusion amongst the members of board for participating and contributing to the Capacity Assessment program. The board members agreed to build up the relations with the organisation by first strengthening the nucleus of the organisation (BOD and GM in the case) and continuously working the way to middle (middle management; Department Heads, Branch Managers) and outer (first level employees) spheres of the net.

Demonstration with a healthy onion and a semi rotten onion also projected more than the necessary clues to define that only around strong core structure healthy layers can be built where a decaying core will only add other decoyed layers creating an overall unhealthy product. Apple's marketing, at its "core", is more like an onion. Separate, individual layers that all come together to create the whole picture. At every stage of a product's development or marketing, there is input, evaluation, and ideas. Don't think of Apple as having a single "marketing department" that controls all its advertising and design, rather, the whole company, and its customers, are the marketing department. ${ }^{8}$

\subsection{Briefing the staff and motivating them for professional participation and contribution}

Up to the date when the employees were introduced to a complex program of Capacity Assessment, only some of them had attended to mostly single day conferences and trainings. Introductions were done in three groups of average 50 people and special attention was paid that each group consists of employees from all levels. Reluctant to attend top management were given the task to organise and lead the meetings to ensure their participation. Capacity Assessment specialists supervised the meetings and to overcome the major concern and confusion of the participants in "how the result of the program will affect them individually", the employees were encouraged to work on the individual and corporate benefits and challenges that might arise from the implementation of Capacity Assessment. Some definitions of capacity cited above were shared with and the staff.

\subsection{Drawing the questioner with key participants and forming the Balanced Scorecard}

A questioner was produced with extensive contribution of 35 employees from different hierarchies including representation from BOD, GM, and various departments and branches.BOD was presented the questioner to ensure everyone's involvement and approval on the questions selected. BOD approved and confirmed the use of the questioner as it was drafted.

The Balanced Scorecard (BSC) is a strategic performance management framework that allows organizations to manage and measure the delivery of their strategy. The concept was initially introduced by Robert Kaplan and David Norton in a Harvard Business Review Article in 1992 and has since then been voted one of the most influential business ideas of the past 75 years (Kaplan and Norton, 1992).

About half of major companies in the US, Europe and Asia are using Balanced Scorecard Approaches. The exact figures vary slightly but the Gartner Group suggests that over $50 \%$ of large US firms had adopted the BSC by the end of 2000. A study by Bain \& Co finds that about $44 \%$ of organizations in North America use the Balanced Scorecard and a study in

${ }^{8}$ Sherice Jacob http:/ / blog.kissmetrics.com/how-apple-changed-the-world/ 
Germany, Switzerland, and Austria finds that $26 \%$ of firms use Balanced Scorecards. The widest use of the Balanced Scorecard approach can be found in the US, the UK, Northern Europe, and Japan'.

A process with no real management commitment will be compromised from the start. As important as senior management's commitment is, it is important to have the full support of the individuals in middle management or front line supervision whose support, or lack thereof, can make or break the process, hence, prior to the assessment, a steering team (from both sides) comes together to agree the plan, clarify objectives and commit their organization, team or group to support the assessment process. The senior decision-makers of relevant organization then need to foster support and leverage resources within their own organization or team, e.g. dedicated time and availability from specific people (Shamugia, 2008).

Even though this process looked like a preparatory stage, the training was already on and the preparations for Capacity Assessment were triggering the employees to improve their knowledge and various skills like effective communication and teamwork. The questioner as shown in Table 1 contained a total of 42 capabilities reflecting corporate value, work attitude, communication, leadership, team spirit, customer relations, marketing, and crises handling etc. The questioner provided possibility to cross check statements of employees by forwarding to all, questions like "who are the usual early birds?", "who are the social event fans?", "who do you work with greatest pleasure?","who is strictly affiliated to the corporate uniform?"...

The questioner also included criteria to evaluate the overall emotional situation of the employee, matters like household issues affecting them, distance of residence and travel means and times. The questioner additionally provided section for "Destination Statement"10 to encourage the employees to express their comments on their current position and future expectations.

At this stage, the participants were briefed for Capacity Assessment methodologies and the use of Balanced Scorecard. Participants evaluated three generations of Balanced Scorecard practise and for initial Capacity Assessment agreed on a general format respecting the basics (The 4 box system in grading) and current achievements in using Balanced Scorecard.

A grading system 1-4 was built in the Balanced Scorecard where, Capacity graded as 1 needs urgent improvement, Capacity graded 2 is improvable, Capacity graded 3 is improving to satisfaction, and Capacity graded 4 is efficiently improved.

The Balanced Scorecard included a third generation feature; section for the assessed to define their own targets in improvement with times for such stated. Definition Statement concept was thus introduced to the assessed to contribute also to their evolvement for Self Assessment in future Performance Evaluation programs.

During the 10 years since the advent of Balanced Scorecard, many changes have been made to the physical design, utility and the design processes used to create the tool within organisations. This evolution of Balanced Scorecard, at least in terms of these three parameters, can be largely attributed to empirical evidence driven primarily by observed weaknesses in the design process

\footnotetext{
9 http://www.ap-institute.com/ Balanced \%20Scorecard \%20How \%20many \%20companies \%20use \%20this \%20tool.html

${ }^{10}$ Destination Statement is an improvement used in 3rd generation balanced scorecards
} 


\begin{tabular}{|c|c|c|c|}
\hline \multicolumn{4}{|l|}{ NAME } \\
\hline \multicolumn{4}{|l|}{ SURNAME } \\
\hline \multicolumn{4}{|l|}{ BRANCH } \\
\hline \multicolumn{4}{|l|}{ TITLE } \\
\hline \multicolumn{4}{|l|}{ POSITION } \\
\hline \multicolumn{4}{|l|}{ WORK START DATE } \\
\hline \multicolumn{4}{|l|}{ EDUCATION STATUS } \\
\hline \multicolumn{4}{|l|}{\begin{tabular}{|l|} 
PARTICIPATIONS IN \\
TRAINING PROGRAMS
\end{tabular}} \\
\hline CAPABILITIES & 2 & 3 & 4 \\
\hline \multicolumn{4}{|c|}{ 1) The knowledge about the Bank products (credit types etc.) } \\
\hline \multicolumn{4}{|c|}{ 2)Observation and ability to understand customer need } \\
\hline \multicolumn{4}{|c|}{$\begin{array}{l}\text { 3) Understanding the Customer needs and matching them with } \\
\text { bank policies. }\end{array}$} \\
\hline \multicolumn{4}{|c|}{ 4)The ability to offer innovative recommendations } \\
\hline \multicolumn{4}{|c|}{$\begin{array}{l}\text { 5)The ability to offer new products to existing and new customer } \\
\text { (up selling skills) }\end{array}$} \\
\hline \multicolumn{4}{|l|}{ 6)Communications skills } \\
\hline \multicolumn{4}{|c|}{ 7)The quality of service provided } \\
\hline \multicolumn{4}{|c|}{ 8)Average processing times for primary operations } \\
\hline \multicolumn{4}{|c|}{ 9)Communications with colleagues } \\
\hline \multicolumn{4}{|c|}{$\begin{array}{l}\text { 10)Ability to communicate with customers with exaggerated } \\
\text { expectations }\end{array}$} \\
\hline \multicolumn{4}{|c|}{ 11)Trainings attended for dealing with problematic customers } \\
\hline \multicolumn{4}{|c|}{ 12) Trainings attended for solving customer problems } \\
\hline \multicolumn{4}{|c|}{ 13) Pre-detection capability for, risk, complications } \\
\hline \multicolumn{4}{|c|}{$\begin{array}{l}\text { 14) The ability to deal with and resolve the } \\
\text { problem/risk/complication }\end{array}$} \\
\hline \multicolumn{4}{|c|}{ 15) Reporting skills for unresolved problems authority } \\
\hline \multicolumn{4}{|l|}{ 16)Corporate Dress attire } \\
\hline \multicolumn{4}{|c|}{ 17)Punctuality and regularity } \\
\hline \multicolumn{4}{|c|}{ 18)The frequency of sick leave and other excuses } \\
\hline \multicolumn{4}{|c|}{ 19)Participations in development programmes } \\
\hline \multicolumn{4}{|c|}{ 20)Flexibility and adaptability to development skills } \\
\hline \multicolumn{4}{|l|}{ 21)Learning skills } \\
\hline \multicolumn{4}{|c|}{ 22)Skills, abilities and activities except the job } \\
\hline 23)Knowledge in the ban & & & \\
\hline $\begin{array}{l}\text { 24)Ability to comply with } \\
\text { compliances }\end{array}$ & & & \\
\hline
\end{tabular}


25)Compliance with the teamwork skills

26)The ability to motivate his teammates

27)Leadership and management skills

28)Presentation capabilities

29)Relations with subordinates

30)The number of staff working under the control of

31)Main concerns about the performance of his subordinates when he is absent

32)Overall concerns when absent

33)Strains in the absence of his staff

34)Ability to solve staff matters on his own

35)Reporting frequency of staff matters to the management

36)Reporting to

37)Last branch or department meeting attended

38)Solve his own individual problems

39) Referring the individual problems to the administrator

40)How does he analyze the problems in the absence of the branch manager

41)Foreign languages spoken

42)The level of foreign languages spoken

External factors effecting the emotional condition of the employee and Destination Statement

1) Number of employed family members living together

2) Number of dependant family members living together

3) Distance of the residence

4) Transport means to and from the work

5) Social weekly activities

6) Weekly or periodical sports activities

Suggestions of the employee

Destination Statement of the employee

Name of the Assessor:

Date of Assessment:

Table 1. Capacity Assessment Scorecard

rather than in the architecture of the original idea. The need to have a design process that made measure selection more relevant and part of the collective view of the management team drove the major changes that can be seen in two subsequent generations of Balanced Scorecard from the original concept. However, while empirical developments were the mainstay of the evolution of Balanced Scorecard certain aspects of the evolution rationale can be paralleled to pre-existing academic philosophies relating to organisational management and strategic thinking. The 
alignment between developments in Balanced Scorecard principles and the theoretical aspects of control and management process are a positive indication that the more modern ideas about Balanced Scorecard design processes and structure are indeed 'better' than the original concept described by Kaplan and Norton, in so far as they are more likely to have a beneficial consequence for the organisation adopting the tool. However, while more recent Balanced Scorecard designs are substantial improvements on original ideas; there is still room for improvement. 11

\subsection{Interviews for individual capacity assessments}

Interviews to assess the personal capacity were conducted at the branch or department of the employee. Appointments were set in advance and the employees were well informed about the date and time of their assessment interview. Participants' workload and engagements were considered when appointments were set. Holiday and sick leave and other excused were respected and the interviews were arranged to accommodate these.

At the beginning, the two interviewers executed the interviews together. Bank branch with 1 branch manager, 2 assistant managers, and 12 employees of different positions were interviewed. By working together, the two interviewers ensured to use similar scale indicators when grading the employees, who were evaluated by the interviewers, later working each on his own with the interviewed.

Interviews took place in private and no ordinates or subordinates were present at any employee's interview. The interviewers paid attention to the comfort of the employees and tried to gain the trust of employees in the process by implementing the principal that all comments stay confidential except for the final grade and outcomes like suggestions for additional skill trainings and relocating of departments and or branches (See table 1 for a sample).

Duration of interviews depended on various criteria like the range of responsibilities of the employee, willingness of the employee to comment and offer ideas and suggestions for improvement. Most interviews completed in 30-45 minutes. As the interviews progressed, the initial strain and stress signs of the employees decreased significantly. The team sprit evolved and more suggestions and critics increased the data collection.

\subsection{Physical and management capacity assessment of branches and departments}

Work environment has always been a decisive factor on performance of the employees. The Capacity Assessment Team evaluated every Branch and Department during the assessment visits. The physical capacity of the premise was evaluated by observation to define multiple criteria like; Building and work area's ergonomic and corporate design, Efficiency in traffic in the work and customer service areas, Display of information, Existence of employee service and recreational areas, Hospitality desk or area for Customer, Equipment standards and appropriate use, and Parking spaces for staff and customers. We will observe later in this chapter a sample report evaluating the physical and operational capacities of a branch (See Iskele Branch as a sample).

${ }^{11}$ Ian Cobbold and Gavin Lawrie The Development of BSC as a Strategic Management tool, 2GC Limited, 2001, 2003. 


\subsection{Evaluating the data and reporting to BOD}

\subsubsection{Capacity evaluation for each staff}

Capacity Assessment for each employee was evaluated based on the Balanced Scorecard graded and composed during the interviews

i. Numerical Evaluation. The sum of grades (marked 1-4) for each capability, divided to the number of capabilities assessed on the scorecard produces the overall Average Capacity grade of each employee. Scorecard Average (SCA) is thus derived

ii. Comments of Capacity Assessor. Indicates the leadership, communication, sales and other capacities observed, suggests additional training in appropriate disciplines and eventual new job position. Comments about the motivation level and points to psychological needs if any.

iii. Own comments of the assessed. Commitments and Destination Statement of the assessed for building further capabilities.

\subsubsection{Sample of report for Employees' Capacity Evaluation grouped in the branch or department where they work}

As a result, a table was produced for each branch and or department listing every employee and evaluations derived from the collected data. The Table 2 is just a short part of the full table, which was composed for the employees of The Nicosia Main Branch, in Nicosia with total 24 employees. The sample table displays only 5 randomly selected employees. The table clearly exposes the numerical (Scorecard Average) and comments of Capacity Assessor.

\begin{tabular}{|c|l|l|l|l|l|}
\hline Branch & $\begin{array}{c}\text { Employee } \\
\text { Name12 }\end{array}$ & $\begin{array}{l}\text { Capacity Assessors' Comments for } \\
\text { further improvement areas }\end{array}$ & SCA & Capacity Level & Position \\
\hline Main Branch & A.A & $\begin{array}{l}\text { Leadership, Management Skills } \\
\text { courses advised }\end{array}$ & 2.5 & $\begin{array}{l}\text { Improving to } \\
\text { Satisfaction }\end{array}$ & $\begin{array}{l}\text { Assistant to } \\
\text { Branch } \\
\text { Manager }\end{array}$ \\
\hline Main Branch & ED & $\begin{array}{l}\text { Will be more efficient if relocated to } \\
\text { accountancy dept }\end{array}$ & 2.2 & $\begin{array}{l}\text { Improving to } \\
\text { Satisfaction }\end{array}$ & $\begin{array}{l}\text { Starter level } \\
\text { clerk }\end{array}$ \\
\hline Main Branch & AU & $\begin{array}{l}\text { Possesses teaching skills to be } \\
\text { trained as in-house trainer. } \\
\text { Leadership and advanced } \\
\text { communication skills courses } \\
\text { advised. }\end{array}$ & 3.3 & $\begin{array}{l}\text { Efficiently } \\
\text { improved. }\end{array}$ & $\begin{array}{l}\text { Intermediate } \\
\text { leverk }\end{array}$ \\
\hline Main Branch & ÇH & $\begin{array}{l}\text { Effective Communication and } \\
\text { Accounting courses advised }\end{array}$ & 1.8 & improvable, & $\begin{array}{l}\text { Starter level } \\
\text { clerk }\end{array}$ \\
\hline Main Branch & SA & $\begin{array}{l}\text { Leadership, Marketing courses } \\
\text { advised }\end{array}$ & 3.6 & $\begin{array}{l}\text { Efficiently } \\
\text { improved. }\end{array}$ & Manch Vice \\
\hline
\end{tabular}

Table 2. Report for Employees' Capacity Evaluation (Main Branch)

SCA as Scorecard Average can be calculated as "between 00 and 1.0 (needs urgent improvement)", "between 1.1 and 2.0 (improvable)", "between 2.1 and 3.0 (improving to satisfaction)" and "between 3.1 and 4.0 (efficiently improved)".

${ }^{12}$ Full names not reproduced for ethical reasons and privacy respect 


\subsubsection{Physical and operational capacities}

The Capacity Assessors also observed each branch and department visited for Physical and Operational Capacities. The Data collected for these capacities of each branch, was analysed and reported to BOD.

A Physical and Operational Capacities report based on the real report for one branch (Iskele Branch) is partially sampled below. Only the capacities, which need improvement, are summarised and included in this sample.

Iskele Branch is in a relatively distant town (fishing, tourism, agriculture) from the main office. The Branch has 14 employees including the Manager and 2 Shift Leaders. Average Score of the Iskele Branch is calculated as 2.63. The Average Score of the Branch is the figure derived from dividing the sum of all employees' Scorecard Average to the number of employees.

\section{Physical Capacities of Iskele Branch, which need improvement, are stated below:}

- Perfectly located Branch needs architectural reconstruction to reflect the corporate style indoor and outdoor.

- Security of the Branch and the employees is compromised in the current work environment. This elevates the necessity of attention to the reconstruction issue.

- $\quad$ Equipment needs upgrading.

- New architectural solution must allow space for customer hospitality desk to protect the existing friendly work relations with locals

- The character of the rural area demands increased mobility for the branch. Additional vehicle must be provided.

Operational Capacities Iskele Branch, which need improvement are as follows:

- Strong local relations must be capitalised for further growth

- Branch manager to be supported continuously with specific additional trainings to improve to satisfaction his organisational and leadership skills.

- Products related with the rural character of the area must be included to the product range

\subsection{Reporting and suggestions to LTK Bank's BOD}

The Capacity Assessment Team provided to the BOD with the following reports and presentations:

- Capacity Assessment of employees grouped in the department or branch they are positioned (sampled above in table 2).

- Physical and Operational Capacity of each branch or department (Sampled above in Iskele Branch case; 3.7.3).

- General Report covering all the capacities of the LTK Bank aspects stating both the capacities needing priority for improvement and the capacities improved to satisfaction.

Following is an extract from the General Report presented to BOD of LTK Bank. The main findings of report are categorised as advanced capacities of LTK band and Capacities of the bank needing urgent attention for improvements. 


\subsubsection{Advanced capacities}

- Bank employees posses highest level of institutional loyalty

- Work departure / arrival times are in general satisfactory. (Solution to this issue; use exit entry card system!)

- The employees (especially employees with more than 10 years in the bank) demonstrate high level of communication skills, attention, and are active and diligent in introducing the bank's products.

- $\quad$ Significantly high employment continuity helps to keep and improve customer loyalty and encourages applicant and new employees.

- The easy accessibility of senior management even though occasionally disturbs the hierarchical scheme; employees often enjoy the practice and develop higher level of self-confidence.

- A satisfactory number of employees in each branch and department are well acquainted with the customers and possess skills to satisfy individual needs of the customers.

- Solidarity and support among the staff is present at a high and admirable level. This positively affects the performance of the bank and the team work of the employees.

- Board of Directors' job, responsibility, and authority sharing strategy is a major advantage for the bank. This innovative way of management in North Cyprus banks is increasing each BOD member's specialization and effective and efficient management.

\subsection{2 capacities needing urgent attention for improvements}

- Periodic meetings are not regular .The meetings, the agenda and the minutes / reports of branches and departments are not present.

- Bank's regulations are neither well distributed nor well recognised by the employees. Regulations are unknown, except by a minor group.

- Complete restructuring of Human Resources unit is needed.

- Level of staff motivation needs to be increased. In particular, branch managers need to improve their supportive attitude to the employees.

- Individual achievements should not be in front of corporate success. Especially 'We' instead of 'I' should be preferred.

- Hierarchical structure within the bank must be respected.

- Access and facilities for disabled must be present and or improved.

- Branches must project the corporate design and identity.

- Marketing is the capacity, which needs immediate improvement.

- Marketing Department needs to be restructured as quickly as possible, with welltrained and energetic staff.

- Unique to each region-specific marketing campaign. Credit expansion of the region's needs to be identified and developed.

- Closed circuit TV screens (LCD), in each branch can be used to promote the products and services offered.

- Customer preparatory desk (pens, forms, calculators, product brochures, and even an internet connection) should be designed for all branches.

- Customer profile is aging. Aim for a young customer profile. Note that young people are future customers. Especially important in this sense are marketing points at the university campuses.

- Develop relationships with State and local government agencies and institutions in regions. 
- Improve communication with Main Office by using online IT software to find earlier solutions to special customer demands such as insurances, special credits etc.

- Marketing Department at the Main Office must consider regional marketing needs and provide solutions and support.

- Internet banking and customer service must be introduced with no delay.

- Hospitality Desk (The concept of hospitality) as a pilot study in a small branch must also be tested in a larger branch.

- Risk management is a very urgent need and priority should be the establishment of a new department as soon as possible. At the present, the individuals assigned to this task lack the knowledge and experience. Expert service must be outsourced to save time and avoid legal strains.

- Contemporary banking technologies need to be available in all branches and not only in the new ones.

- Compliance with existing regulations of dress is generally observed. However, the colours used are incompatible with the vision of the bank. Black represents the colour of authority and seriousness.

- The senior management is selectively far too easily accessible and this creates hierarchic disorders of communication between administrative staff.

- Personal Banking must be introduced to create an upper hand in competition with other banks.

- Branches need to have meeting rooms to provide service that is more efficient to the customers. The current practice of inviting the customers behind the service bench is outdated and projects selective servicing of some customers while carries risk for confidential data to be exposed

- Marketing products offered by the bank should not be competing with each other.

- In some branches, the bank asks for customer's password when providing service related with Debit cards. These practices have to be abandoned immediately since it may lead to security and legal drawbacks.

- Cleaning and maintenance done by bank staff is not at the expected highest level. Outsourcing these services will bring more efficiency.

\subsection{Summary of trainings as an outcome of the capacity assessment program}

Education and Trainings; Communication Skills verbal and written, Presentation skills, Ethics and Banking Ethics, Leadership, Crises Management, Advanced English Language, Report Writing skills of staff were improved by providing education and training programs to the employees in harmony with the outcome of Capacity Assessment.

A group of 30 employees were trained on Performance Evaluation and Methods, Objective Evaluations, Interview skills, this group drafted the Performance Evaluation Balanced Scorecard majorly applying the 360-Degree Methodology ${ }^{13} .8$ of this group were appointed as in-house Performance Evaluators and after practising, they conducted Performance

\footnotetext{
${ }^{13}$ The performance feedback method known as 360-degree feedback has gained wide popularity in the corporate world to the point of being nearly universal among Fortune 500 companies. A 360-degree feedback program enables organizational members to receive feedback on their performance, usually anonymously, from all the major constituencies they serve. (Jai Ghorpade Managing Five Paradoxes of 360-Degree Feedback. Academy of Management Feb., 2000
} 
Evaluation under loose supervision of The Capacity Assessment Team. The results were supporting the necessity of trainings and programs provided and justifying the suggestions made to BOD in the General Report of the Capacity Assessment Team ${ }^{14}$.

\section{Conclusion}

In this study, capacity assessment program was applied to Limassol Turkish Cooperative Bank in Northern Cyprus. Expectedly, positive contributions of this program started to be observed just after the implementation of the program.

LTK Bank in less than a year gained a well-dressed corporate identity. Departments were restructured to more efficiency. Total restructure was in Human Resource Department now performing much more than being a pay-roll office. Information Technology Department rise to the level to meet both customer and Bank's needs. A proactive Marketing Department harmonised the existing products and constantly is researching and designing new general and specific to the area products. Young customers are targeted with products offering them solutions for financing their education and or new profession. A small number of staff (6) was relocated to alternative departments. Limited numbers of staff (2) were contributed to improve their emotional well being by professional attention and paid recreational holiday. Two top-level managers and one member of the board enrolled to 8 weeks Executive Bank Management Training.16 new jobs were created in the bank at specialised and starter levels. LTK Bank became more visible with additional social responsibility programs.

As in any other Capacity Development program, the method used during this study lacked the capability of bringing to surface some of the significant human factors in any operation. There were no tested tools to understand if the mature staff who occupy executive positions are more interested in their retirement plans or the strategic improvement of the of the organisation in next 10 years. Likewise, we could not verify how devoted is the junior employees to the Bank. The program provided too little information for the assessors to trace or to link the psychological discomforts (if any) with the management styles of the bank or the leading methods of the nearest administrator.

Without a comprehensive Capacity Assessment, LTK Bank could still be wondering how to meet the new challenges. The implemented Capacity Assessment gave the opportunity to the Bank to learn 'what their staffs are made from'. This knowledge was much easier to obtain and more economic than costly new management and new staff contracts. It also improved the positive image amongst stakeholders as an institute who cares and contributes to existing employees rather than terminating their contracts. It also provides a fair and transparent quality to the recruitment policies of the LTK Bank.

The program will lay strong foundations to the organisation's further Capacity Development. Education and Training provided must be tested for outcome. Biannual Performance Evaluations performed by trained corporate in-house assessors must be crosschecked with external expert assessors until the derivations in the results are diminishingly narrow. Researches among close stakeholders (Cooperative member

\footnotetext{
14 Another study of the authors' will detail the improvement program and training and conducting Performance Evaluation
} 
shareholders, customers, targeted sectors, related institutions such as Central Bank and Finance Ministry) and general stakeholders need to be carried out for both verifying and extending the level of capabilities and newly acquired capacities of the Bank.

\section{Acknowledgment}

- The authors appreciate the wise consent of Dr. Huda Hudaverdi, to use the data of the Capacity Assessment Program to LTK Bank. Dr. H. Hudaverdi was partner in the complete process of Capacity Assessment program and actively participated in every stage of the program.

- The authors acknowledge the significance of the decisions of BOD of LTK Bank and express their gratitude to The Chair, to the Education Member of the Board, and to all executives enabling this study and thank to all employees of the Bank.

\section{References}

Cohen, J., M. (1993). Building Sustainable Public Sector Managerial, Professional, and Technical Capacity: A Framework for Analysis and Intervention. Cambridge, Mass: Harvard Institute for International Development.

Kaplan, Alan (2007), The Core of our Work as Capacity Builders, Annual Report, CDRA.

Kaplan, Robert and David Norton (1992), The Balanced Scorecard-Measures that Drive Performance, Harvard Business Review. 1992, http://hbr.org/1992/01/thebalanced-scorecard-measures-that-drive-performance

Lusthaus, Charles, Marie-Hélène Adrien and Mark Perstinger (1999), “Capacity Development: Definitions, Issues and Implications for Planning, Monitoring and Evaluation", Universalia Occasional Paper, No. 35, September 1999

Lusthaus, C.; Adrien, M. H.; Anderson, G.; \& Carden, F. (1999). Enhancing Organizational Performance: A Toolbox for Self-Assessment. Montreal: Universalia.

Morgan, P. (2006), The Concept of Capacity, EUROPEAN CENTRE FOR DEVELOPMENT POLICY MANAGEMENT (ECDPM).

OECD (2006), DAC Guidelines and Reference Series Applying Strategic Environmental Assessment: Good Practice Guidance for Development Co-operation, OECD, Paris

OECD-DAC Network on Governance (2006), The Challenge of Capacity Development: Working towards Good Practice, 2006, p.7.

Saskatoon, Saskatchewan (2004), HEALTH PROMOTION CAPACITY CHECKLISTS: A Workbook for Individual, Organizational, and Environmental Assessment, Prairie Region Health Promotion Research Centre, University of Saskatchewan, Canada.

Shamugia, Ivane (2008), UNDP Georgia Methodology for Quick Capacity Assessment, November, 2008.

UNDP. (1997). Capacity Development. New York: Management Development and Governance Division, UNDP.

UNDP (1998), Capacity Assessment and Development in a Systems and Strategic Management Context, Technical Advisory Paper No. 3, Management Development and Governance Division Bureau for Development Policy, January 1998

UNDP (2006), Practice Note: Capacity Development, July 2006

UNDP (2007), Capacity Assessment Practice Note, Feb. 2007, p.5.

UNDP (2008), Practice Note: Capacity Assessment, September 2008

UNDP (2009), Capacity Development Group - June 2009 


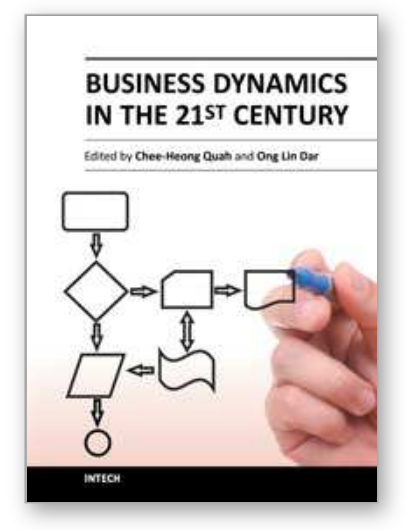

\author{
Business Dynamics in the 21st Century \\ Edited by Dr. Chee-Heong Quah
}

ISBN 978-953-51-0628-9

Hard cover, 260 pages

Publisher InTech

Published online 23, May, 2012

Published in print edition May, 2012

In this 21 st century of opportunity and turbulence, business firms need to equip themselves with new competencies that were never thought of before. For this reason, this book is timely as it introduces new insights into new problems in the aspects of performance and quality improvement, networking and logistics in the interconnected world, as well as developments in monetary and financial environment surrounding private enterprises today. Readers shall find that reading this book is an enlightening and pleasant experience, as the discussions are delivered in a clear, straightforward, and "no-frills" manner - suitable to academics and practitioners. If desired, the book can serve as an additional piece of reference for teaching and research in business and economics.

\title{
How to reference
}

In order to correctly reference this scholarly work, feel free to copy and paste the following:

Mustafa Ertanın and Okan Veli Şafaklı (2012). Capacity Assessments for Improving Corporate Efficiency Case of Limassol Turkish Cooperative Bank in Northern Cyprus, Business Dynamics in the 21st Century, Dr. Chee-Heong Quah (Ed.), ISBN: 978-953-51-0628-9, InTech, Available from: http://www.intechopen.com/books/business-dynamics-in-the-21st-century/capacity-assesment-for-improvingcorporate-efficiency-case-of-limassol-turkish-cooperative-bank-in-n

\section{INTECH}

open science | open minds

\author{
InTech Europe \\ University Campus STeP Ri \\ Slavka Krautzeka 83/A \\ 51000 Rijeka, Croatia \\ Phone: +385 (51) 770447 \\ Fax: +385 (51) 686166 \\ www.intechopen.com
}

\author{
InTech China \\ Unit 405, Office Block, Hotel Equatorial Shanghai \\ No.65, Yan An Road (West), Shanghai, 200040, China \\ 中国上海市延安西路65号上海国际贵都大饭店办公楼405单元 \\ Phone: +86-21-62489820 \\ Fax: $+86-21-62489821$
}


(C) 2012 The Author(s). Licensee IntechOpen. This is an open access article distributed under the terms of the Creative Commons Attribution 3.0 License, which permits unrestricted use, distribution, and reproduction in any medium, provided the original work is properly cited. 